\title{
Antioxidant, antibacterial, cytotoxic, and apoptotic activity of stem bark extracts of Cephalotaxus griffithii Hook. $f$
}

\author{
Dinesh Singh Moirangthem ${ }^{1}$, Narayan Chandra Talukdar ${ }^{\text {* }}$, Naresh Kasoju ${ }^{2}$ and Utpal Bora ${ }^{2}$
}

\begin{abstract}
Background: Cephalotaxus spp. are known to possess various therapeutic potentials. Cephalotaxus griffithii, however, has not been evaluated for its biological potential. The reason may be the remoteness and inaccessibility of the habitat where it is distributed. The main aim of this study was to: (1) evaluate multiple biological potentials of stem bark of $C$. griffithii, and (2) identify solvent extract of stem bark of $C$. griffithii to find the one with the highest specific biological activity.

Methods: Dried powder of stem bark of C. griffithii was exhaustively extracted serially by soaking in petroleum ether, acetone and methanol to fractionate the chemical constituents into individual fractions or extracts. The extracts were tested for total phenolic and flavonoid content, antioxidant (DPPH radical scavenging, superoxide radical scavenging, and reducing power models), antibacterial (disc diffusion assay on six bacterial strains), cytotoxic (MTT assay on HeLa cells), and apoptotic activity (fluorescence microscopy, DNA fragmentation assay, and flow cytometry on HeLa cells).
\end{abstract}

Results: Among the three extracts of stem bark of C. griffithii, the acetone extract contained the highest amount of total phenolics and flavonoids and showed maximum antioxidant, antibacterial, cytotoxic $\left(I C_{50}\right.$ of $35.5 \pm 0.6 \mu \mathrm{g} / \mathrm{ml}$; $P<0.05)$, and apoptotic $(46.3 \pm 3.6 \%$ sub-G0/G1 population; $P<0.05)$ activity, followed by the methanol and petroleum ether extracts. However, there was no significant difference observed in $\mathrm{I}_{50}$ values (DPPH scavenging assay) of the acetone and methanol extracts and the positive control (ascorbic acid). In contrast, superoxide radical scavenging assay-based antioxidant activity $\left(\mathrm{IC}_{50}\right)$ of the acetone and methanol extracts was significantly lower than the positive control $(P<0.05)$. Correlation analysis suggested that phenolic and flavonoid content present in stem bark of $C$. griffithii extracts was responsible for the high antioxidant, cytotoxic, and apoptotic activity $(\mathrm{P}<$ 0.05).

Conclusions: Stem bark of C. griffithii has multiple biological effects. These results call for further chemical characterization of acetone extract of stem bark of C. griffithii for specific bioactivity.

Keywords: Cephalotaxus griffithii, Polyphenol, Antioxidant, Antibacterial, Cytotoxicity, Apoptosis

\section{Background}

Cephalotaxus griffithii Hook. f., a gymnosperm belonging to the family Cephalotaxaceae, is commonly known as Griffith's plum yew. A shrub or small tree, it is found up to an altitude of $2000 \mathrm{~m}$ and is distributed in northeastern

\footnotetext{
* Correspondence: nayan.ibsd@nic.in

'Institute of Bioresources and Sustainable Development, Department of Biotechnology, Government of India, Takyelpat Institutional Area, Imphal 795001, Manipur, India

Full list of author information is available at the end of the article
}

India, western Sichuan province in China, and Myanmar [1]. Traditional healers of Manipur, a northeastern state of India, use tablets made from C. griffithii bark to treat cancer. Cephalotaxus spp. have previously been reported to exhibit various biological activities including anticancer [2], osteoblast differentiation [3] and antioxidant activity [4]. It has also been reported that the flavonoids present in Cephalotaxus spp. were mainly responsible for such biological activities [2-4]. However, research on C. griffithii has been very limited. This may be because of the remoteness

\section{() Biomed Central}


and limited accessibility of the habitat of this species. So far, only two phytochemical analyses from $C$. griffithii have been attempted. Kamil et al. [5] isolated and characterized six flavonoids, and Phutdhawong et al. [6] carried out chemical analysis of volatile oil from needles of C. griffithii. To our knowledge, to date no data are available on the biological effects of phytochemicals extracted from C. griffithii. The main aim of this study was therefore to: (1) evaluate the biological potential of stem bark of Cephalotaxus griffithii (SBCG), and (2) identify solvent extract of stem bark of $C$. griffithii to find the one with the highest specific biological activity.

\section{Results}

Extraction yield, total phenolic and flavonoid content

Table 1 shows the extraction yield, total phenolic content (TPC), and total flavonoid content (TFC) of SBCG extracts. The TPC and TFC in the three extracts were in a range of $72.5 \pm 5.1 \mathrm{mg}$ to $609.6 \pm 10.1 \mathrm{mg}$ gallic acid equivalents $(\mathrm{GAE}) / \mathrm{g}$ dried extract and $7.6 \pm 0.6 \mathrm{mg}$ to $19 \pm 0.6 \mathrm{mg}$ quercetin equivalents $(\mathrm{QE}) / \mathrm{g}$ dried extract, respectively, with the highest content found in the acetone (ACE) extract followed by the methanol $(\mathrm{MeOH})$ and petroleum ether $(\mathrm{PE})$ extracts $(\mathrm{P}<0.05)$.

\section{Antioxidant activity}

Antioxidant potency was tested for DPPH radical scavenging activity, superoxide radical scavenging (SORS) activity, and reducing power, with results shown in Figures 1, 2 and 3. Irrespective of the extracts, DPPH radical scavenging activity was found to be concentration dependent (Figure 1) with highest activity in the ACE extract followed by the $\mathrm{MeOH}$ and PE extracts. Table 2 shows the $\mathrm{IC}_{50}$ values for the positive control (ascorbic acid) and the three extracts, with a lower $\mathrm{IC}_{50}$ indicating greater scavenging power. No significant difference was found between the DPPH IC 50 values of the ACE and $\mathrm{MeOH}$ extracts of SBCG and the positive control. Figure 2 shows SORS activity of SBCG extract and ascorbic acid. The SORS activity was dose dependent. SORS data for the PE extract were not recorded due to precipitation. The ACE extract possessed higher SORS activity than the $\mathrm{MeOH}$ extract. The $\mathrm{IC}_{50}$ values of these two SBCG extracts were significantly lower than that of the control antioxidant (ascorbic acid) $(\mathrm{P}<0.05)$ (Table 2). The reducing power activity was also dose dependent (Figure 3) with the highest activity found in ascorbic acid. Reducing power of the PE extract was also not recorded because of precipitation, and the ACE extract exhibited higher reducing power than the $\mathrm{MeOH}$ extract.

\section{Antibacterial activity}

Table 3 shows the inhibition zone diameter of six bacterial pathogens due to the application of two reference antibiotics (neomycin and penicillin) and the three extracts at concentrations of $4 \mu \mathrm{g} / \mathrm{disc}$ and $1000 \mu \mathrm{g} /$ disc, respectively. The ACE extract produced the largest diameter of inhibition zone (10.8-15.6 mm). Figure 4 shows the inhibition zone of one test organism, Klebsiella pneumoniae, towards a graded dose of ACE extract. The negative control showed no inhibition zone (data not shown). The minimum inhibitory dose (MID) of the ACE and $\mathrm{MeOH}$ extracts for the three sensitive pathogens were found to be in the range of 31.2-62.5 $\mu \mathrm{g} /$ disc and $125 \mu \mathrm{g} /$ disc, respectively (Table 4). The PE extract inhibited only Klebsiella pneumoniae and the MID was $500 \mu \mathrm{g} /$ disc.

\section{Effects of different extracts on the proliferation of HeLa cells}

Figure 5 shows the percentage of viable HeLa cells after treatment with the three SBCG extracts. The relative number of surviving cells decreased in a dose-dependent manner, although there was no significant difference observed between the four lowest concentrations in PE, three lowest concentrations and two highest concentrations in the ACE extract, and four lowest concentrations in $\mathrm{MeOH}$ extract. Treatment with the ACE extract produced the greatest concentration-dependent response. For example, ACE extract at $5-80 \mu \mathrm{g} / \mathrm{ml}$ decreased the proliferation of HeLa cells by $95 \%$ to $35 \%$. On the other hand, $5-80 \mu \mathrm{g} / \mathrm{ml}$ of either the $\mathrm{MeOH}$ or PE extract decreased the viable cells by $96 \%$ to $43 \%$ and $101 \%$ to $75 \%$, respectively. Correspondingly, the $\mathrm{IC}_{50}$ value of the ACE extract $(35.5 \pm 0.6 \mu \mathrm{g} / \mathrm{ml})$ was found to be the lowest compared with the $\mathrm{MeOH}$ extract $(75.01 \pm 3.4 \mu \mathrm{g} / \mathrm{ml})$ and $\mathrm{PE}$ extract $(156.07 \pm 5.7 \mu \mathrm{g} / \mathrm{ml})(\mathrm{P}<0.05)$. The positive control

Table 1 Extraction yield, TPC, and TFC of SBCG extracts

\begin{tabular}{llll}
\hline Extract & Yield (\% w/w) & $\begin{array}{l}\text { Total phenolic content } \\
\text { (mg GAE/g extract) }\end{array}$ & $\begin{array}{l}\text { Total flavonoid content } \\
\text { (mg QE/g extract) }\end{array}$ \\
\hline Petroleum ether & 0.9 & $72.5 \pm 5.1 \mathrm{a}$ & $7.6 \pm 0.6 \mathrm{a}$ \\
Acetone & 11.2 & $609.6 \pm 10.1 \mathrm{~b}$ & $19 \pm 0.6 \mathrm{~b}$ \\
Methanol & 6.3 & $420.7 \pm 14.5 \mathrm{c}$ & $11.2 \pm 0.3 \mathrm{c}$ \\
\hline
\end{tabular}

Mean \pm SD $(n=3)$

Means marked with different letters, within each column, are significantly different $(P<0.05)$ 


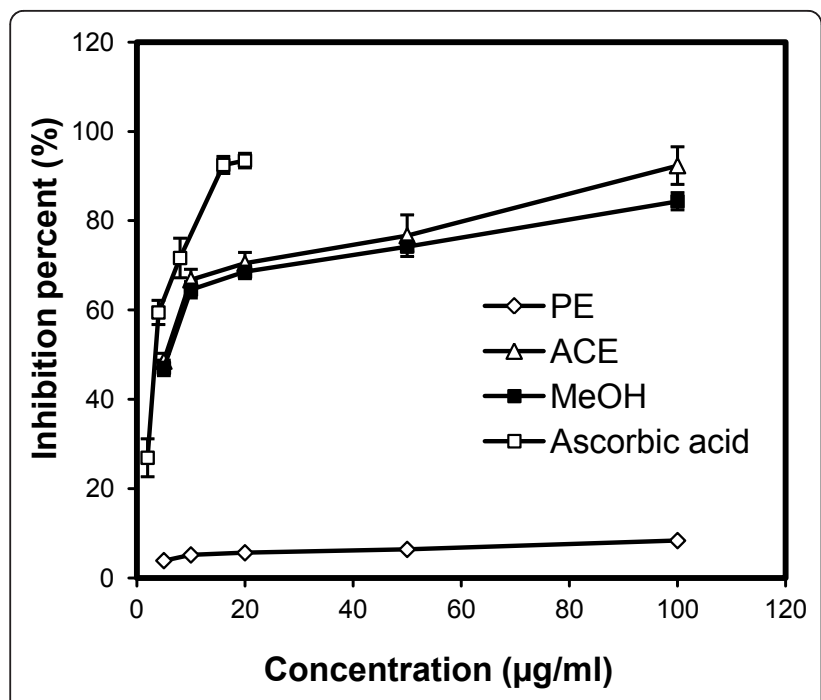

Figure 1 Antioxidant activity of the $\mathrm{PE}, \mathrm{ACE}$, and $\mathrm{MeOH}$ extracts of SBCG and ascorbic acid (positive control) assessed by the DPPH radical scavenging method. Each value represents the mean \pm SD of three determinations.

(curcumin) was found to have an $\mathrm{IC}_{50}$ value of $6.8 \pm 1.4$ $\mu \mathrm{g} / \mathrm{ml}$ (data not shown).

\section{Effects of different extracts on inducing apoptosis of} HeLa cells

Figure 6 shows the appearance of stained HeLa cells under fluorescence microscopy after treatment with the three extracts. The density of HeLa cells, emitting green fluorescence, was lowest due to treatment with the ACE extract, followed by that due to treatment with the

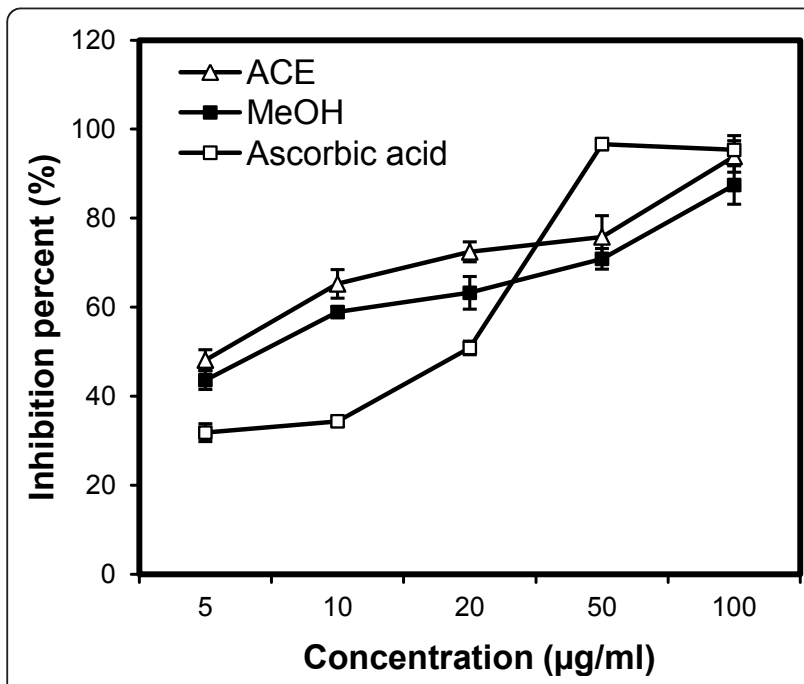

Figure 2 Antioxidant activity of the ACE and $\mathrm{MeOH}$ extracts of SBCG and ascorbic acid (positive control) assessed by the superoxide oxide radical scavenging method. Each value represents the mean \pm SD of three determinations.

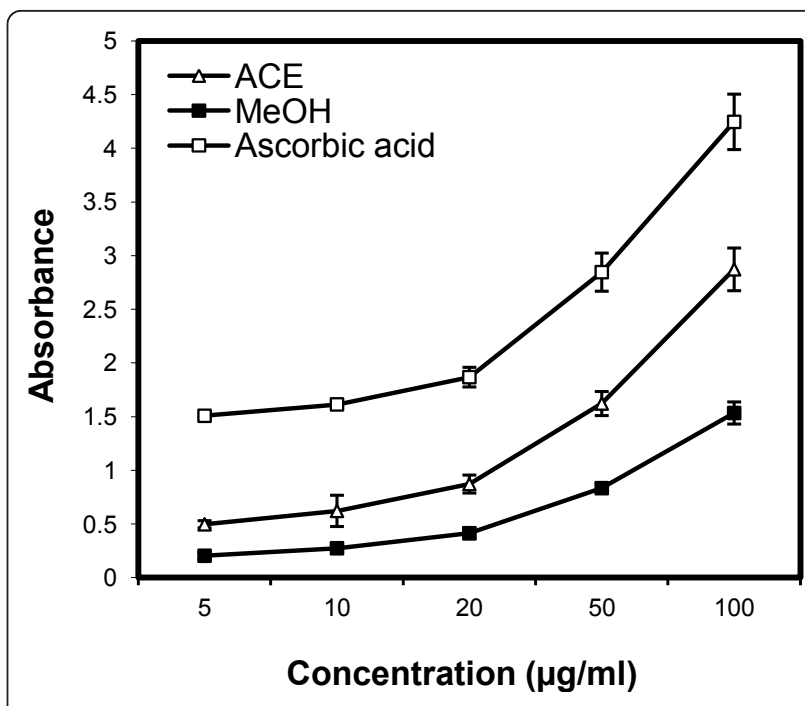

Figure 3 Antioxidant activity of the ACE and $\mathrm{MeOH}$ extracts of SBCG and ascorbic acid (positive control) assessed by the reducing power method. Each value represents the mean \pm SD of three determinations.

$\mathrm{MeOH}$ and PE extracts. In other words, there were more dead cells (showing red fluorescence due to AO stain) in the ACE extract treatment group than in the $\mathrm{MeOH}$ and PE extract treatment groups. Characteristic features of apoptotic cells, such as cytoplasmic membrane blebbing, nuclear contraction, nuclear fragmentation, and contact inhibition, were visible at $24 \mathrm{~h}$ after treatment with the extracts. These features were more prominent in the cells treated with the ACE and $\mathrm{MeOH}$ extracts compared with the other treatments (Figure 6C-D). Figure 7 shows results of a DNA fragmentation assay on HeLa cells. DNA fragmentation of extract-treated HeLa cells was comparable with that of cells treated with curcumin, the positive control. Due to a technical reason, a 100-kb ladder marker was used although a 1 -kb ladder would have been ideal. Table 5 shows results of the flow cytometry analysis. The sub-G0/G1 population (of HeLa cells) as a biochemical marker of apoptosis was considerably higher in all the extract-

Table $2 \mathrm{IC}_{50}$ values of different antioxidant assays of SBCG extracts

\begin{tabular}{cll}
\hline Extract & $\begin{array}{l}\text { DPPH radical } \\
\text { scavenging } \\
(\boldsymbol{\mu g} / \mathbf{m l})\end{array}$ & $\begin{array}{l}\text { Superoxide radical } \\
\text { scavenging } \\
(\boldsymbol{\mu g} / \mathbf{m l})\end{array}$ \\
\hline $\begin{array}{c}\text { Petroleum } \\
\text { ether }\end{array}$ & $1139.6 \pm 33.3 \mathrm{a}$ & $\mathrm{ND}$ \\
Acetone & $5.3 \pm 0.4 \mathrm{~b}$ & $5.5 \pm 0.7 \mathrm{a}$ \\
Methanol & $5.8 \pm 0.5 \mathrm{~b}$ & $7.09 \pm 0.5 \mathrm{a}$ \\
Ascorbic acid & $3.4 \pm 0.15 \mathrm{~b}$ & $19.18 \pm 0.49 \mathrm{~b}$ \\
\hline
\end{tabular}

Data expressed as mean \pm SD $(n=3)$

Means marked with different letters, within each column, are significantly different $(P<0.05)$. (ND $=$ not determined) 
Table 3 Antibacterial activity of different SBCG extracts

\begin{tabular}{|c|c|c|c|c|c|}
\hline \multirow[t]{2}{*}{ Bacteria } & \multicolumn{5}{|c|}{ Inhibition zone diameter (mm) } \\
\hline & $\begin{array}{l}\text { PE } \\
(1000 \mu \mathrm{g} / \text { disc })\end{array}$ & $\begin{array}{l}\text { ACE } \\
(1000 \mu \mathrm{g} / \text { disc })\end{array}$ & $\begin{array}{l}\mathrm{MeOH} \\
(1000 \mu \mathrm{g} / \text { disc })\end{array}$ & $\begin{array}{l}\text { Neomycin } \\
(4 \mu \mathrm{g} / \mathrm{disc})\end{array}$ & $\begin{array}{l}\text { Penicillin } \\
(4 \mu \mathrm{g} / \mathrm{disc})\end{array}$ \\
\hline Klebsiella pneumoniae & $7.1 \pm 0.28$ & $15.6 \pm 0.2$ & $9.16 \pm 0.2$ & $14.5 \pm 0.0$ & ND \\
\hline Pseudomonas aeruginosa & 0 & 0 & 0 & $14.1 \pm 0.2$ & ND \\
\hline Escherichia coli & 0 & $10.83 \pm 0.2$ & $8.83 \pm 0.2$ & $14.1 \pm 0.2$ & ND \\
\hline Bacillus subtilis & 0 & 0 & 0 & $9 \pm 0.0$ & ND \\
\hline Bacillus cereus & 0 & 0 & 0 & $7 \pm 0.0$ & ND \\
\hline Staphylococcus aureus & 0 & $10.8 \pm 0.7$ & $8.8 \pm 0.2$ & 0 & $12 \pm 0.0$ \\
\hline
\end{tabular}

Data expressed as mean \pm SD $(n=3)$.

$(\mathrm{ND}=$ not determined $)$

treated groups compared with the untreated control. The ACE extract resulted in the highest population of $46.3 \pm 3.6 \%$ in $(\mathrm{P}<0.05)$ followed by the $\mathrm{MeOH}$ extract $(35.2 \pm 4.4 \%)(\mathrm{P}<0.05)$ and then the PE extract $(9.1 \pm$ $0.8 \%)$. The population of cells in other phases (G1, S, and G2) of the cell cycle were lower, irrespective of the extract (data not shown).

\section{Correlation analysis}

As shown in Table 6 we observed a statistically significant correlation between total phenolic and flavonoid content of the three SBCG extracts and their corresponding DPPH $\mathrm{IC}_{50}$, MTT $\mathrm{IC}_{50}$, and sub-G0/G1 population $(\mathrm{P}<0.05)$.

\section{Discussion}

This is the first report on the total phenolic and flavonoid content, antioxidant, antibacterial, cytotoxic, and apoptotic activities of stem bark extracts of $C$. griffithii. The total content of phenolic and flavonoid was highest in the ACE extract followed by the $\mathrm{MeOH}$ and PE extracts. Earlier

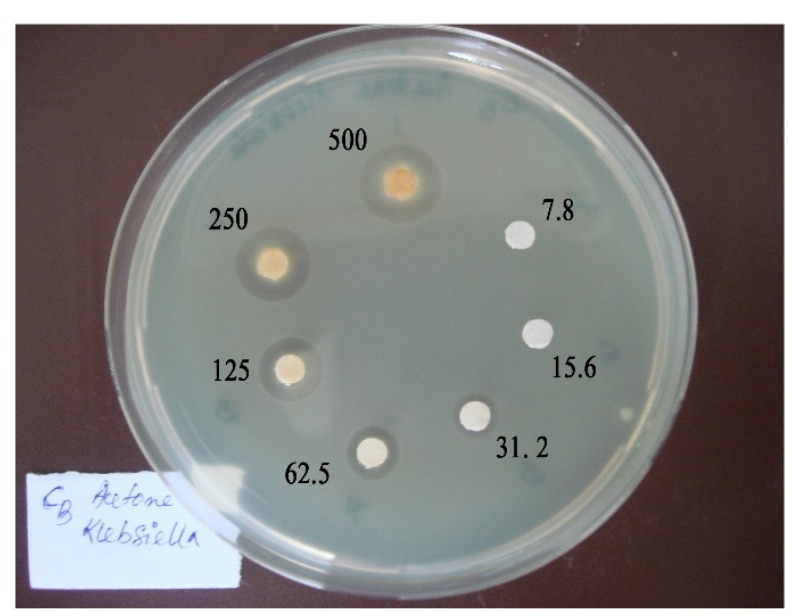

Figure 4 Appearance of the inhibition zones of Klebsiella pneumoniae as a result of application of graded doses (7.8-500 $\mu \mathrm{g} / \mathrm{disc}$ ) of the ACE extract of SBCG. studies reported the occurrence of various flavonoids in other species of Cephalotaxus $[2,7,8]$. Polyphenols and flavonoids of several medicinal plants including Cephalotaxus spp. are known to exhibit multiple biological effects [2-4,9-11]. Therefore, we investigated the polyphenol and flavonoid enriched SBCG extracts for their various biological activities.

The tested extracts and positive control showed antioxidant activity in a dose-dependent manner. Antioxidant activity varied among the extracts and controls. The highest antioxidant activity was observed in the positive control, and among the three extracts the ACE extract showed the highest antioxidant activity followed by the $\mathrm{MeOH}$ and PE extracts. However, there was no statistically significant difference in the DPPH $\mathrm{IC}_{50}$ values among the $\mathrm{ACE}$ and $\mathrm{MeOH}$ extracts and the positive control. In contrast, the $\mathrm{IC}_{50}$ value of SORS activity was significantly (Table $2 ; \mathrm{P}<0.05$ ) lower in both the $\mathrm{ACE}$ and $\mathrm{MeOH}$ extracts compared with the positive control. In several studies, direct relationships have been observed between total phenolic/flavonoid content and plants' antioxidant activity [12-14]. Many studies also showed potential of purified polyphenols in reducing oxidative stress induced by many factors [15-17]. Bae et al. [4] isolated five flavonoids from $C$. koreana, of which four possessed high levels of antioxidant activity based on DPPH radical scavenging and superoxide radical scavenging assays. In agreement with

Table 4 MIDs of different positive SBCG extracts

\begin{tabular}{llllll}
\hline Bacteria & \multicolumn{5}{c}{ Minimum inhibitory dose $(\boldsymbol{\mu g} / \mathbf{d i s c})$} \\
\cline { 2 - 7 } & PE & ACE & MeOH & Neomycin & Penicillin \\
\hline Klebsiella pneumoniae & 500 & 31.2 & 125 & 0.25 & ND \\
Pseudomonas aeruginosa & ND & ND & ND & 0.5 & ND \\
Escherichia coli & ND & 62.5 & 125 & 0.25 & ND \\
Bacillus subtilis & ND & ND & ND & 0.5 & ND \\
Bacillus cereus & ND & ND & ND & 1 & ND \\
Staphylococcus aureus & ND & 31.2 & 125 & ND & 0.25 \\
\hline
\end{tabular}

Data expressed as mean \pm SD $(n=3)$.

$(\mathrm{ND}=$ not determined $)$. 


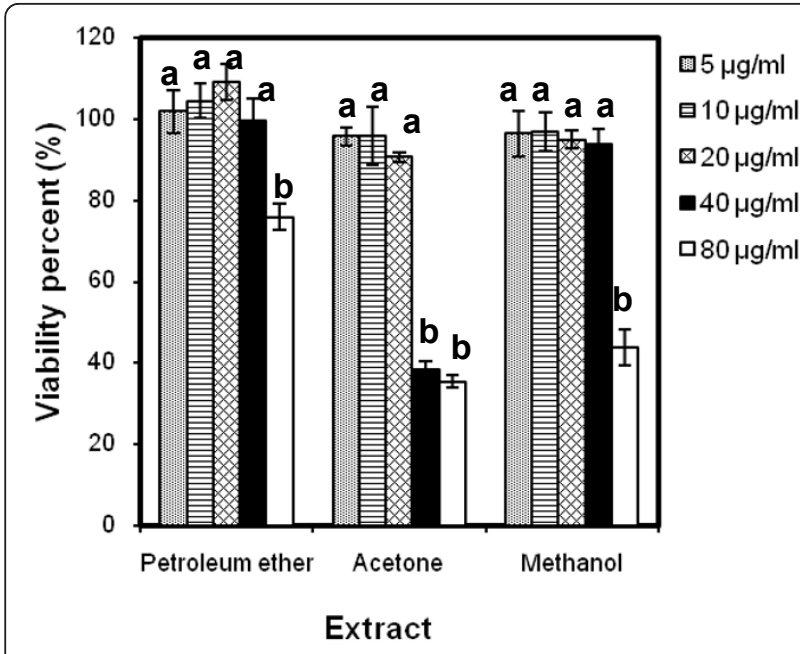

Figure 5 Cytotoxic effect of the $\mathrm{PE}, \mathrm{ACE}$, and $\mathrm{MeOH}$ extracts of SBCG against HeLa cells. Cell survival was determined as the percentage of the control from three independent experiments. Each bar represents the mean $\pm S D(n=3)$. Bars marked without a common letter within each extract are significantly different $(P<0.05)$.

those reports we observed here a statistically significant correlation between phenolic $(\mathrm{r}=0.936, \mathrm{P}<0.05)$ /flavonoid $(\mathrm{r}=0.742, \mathrm{P}<0.05)$ content and the $\mathrm{IC}_{50}$ value of DPPH. This result suggests the presence of potential polyphenols and flavonoids as antioxidants in the SBCG extracts. Antioxidant activity of plant extracts containing polyphenol components is due to their capacity to be donors of hydrogen atoms or electrons and to capture free radicals [18].

The SBCG extracts exhibited differential bacterial inhibitory effects and both the $\mathrm{ACE}$ and $\mathrm{MeOH}$ extracts inhibited only three pathogens, namely Klebsiella pneumoniae, Escherichia coli, and Staphylococcus aureus, out of the six organisms tested. The PE extract inhibited only one strain, Klebsiella pneumoniae. The ACE extract was the most effective among the extracts as it produced a thicker inhibition zone (10.8-15.6 mm) and smaller MID (31.2-62.5 $\mu \mathrm{g} / \mathrm{disc})$ compared with that produced by the other extracts. Polyphenols are well documented for their antibacterial activities $[19,20]$. This underscores the importance of the ACE extract of SBCG which showed the highest antibacterial activity and contained the highest amount of polyphenols and flavonoids among the extracts tested. This inhibition of microorganisms by phenolic compounds may be due to iron deprivation or hydrogen bonding with vital proteins such as microbial enzymes or other interactions to inactivate microbial adhesins, cell envelope transport proteins, and/or nonspecific interactions with carbohydrates, among other possible effects $[19,20]$. Earlier, Cho et al. [21] reported an inhibitory effect of Korean plum yew (C. koreana)

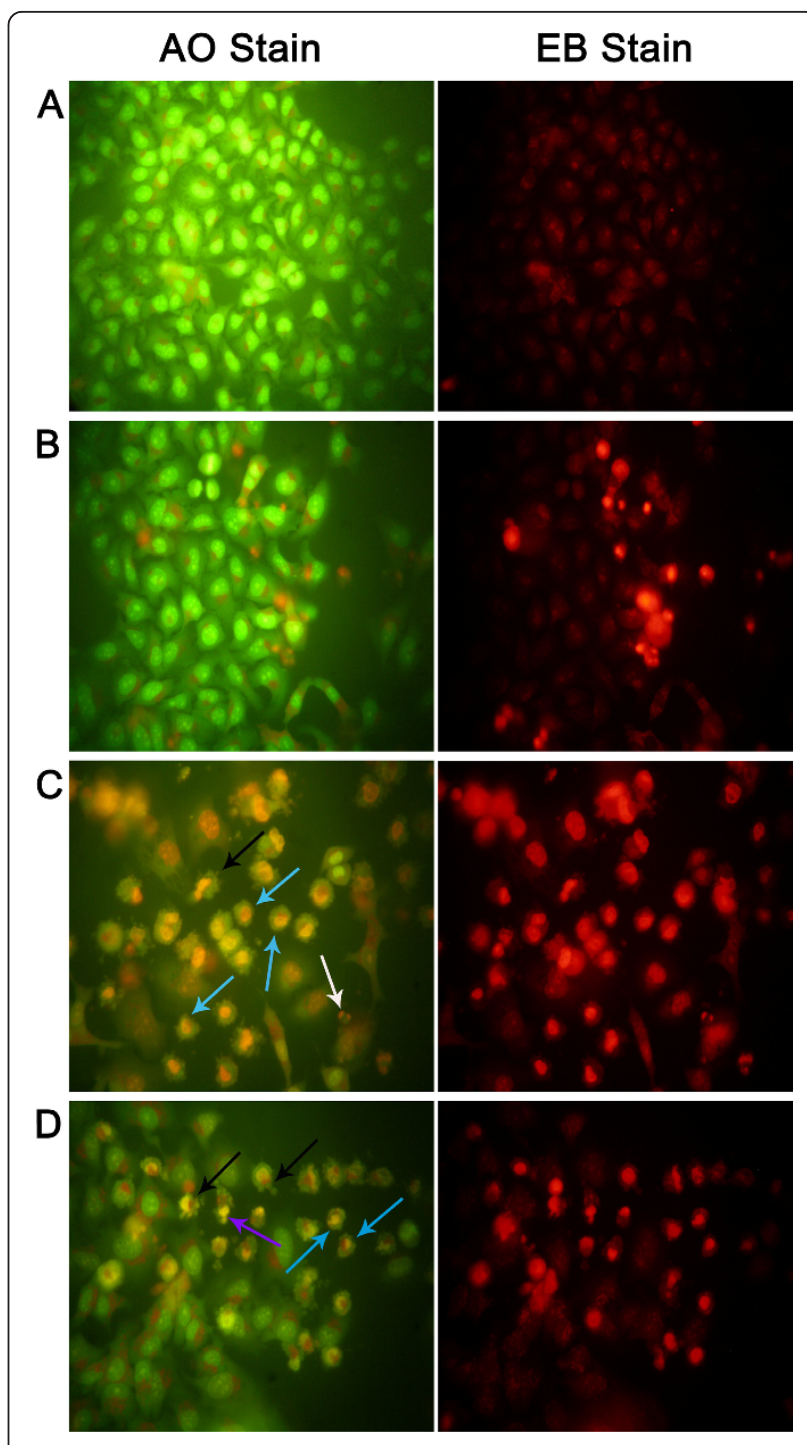

Figure 6 HeLa cells stained with AO/EB and viewed under fluorescence microscope $(400 \times)$ showing apoptosis. (A) Healthy control cells; (B, C and D) Treatment with the PE, ACE, and $\mathrm{MeOH}$ extracts $(80 \mathrm{\mu g} / \mathrm{ml})$ on HeLa cells showing membrane blebbing (black arrow), nuclear condensation (blue arrow), budding to form apoptotic body (purple arrow), nuclear fragmentation (white arrow).

extract on Gram-positive bacteria, Gram-negative bacteria, yeasts, and molds. Similarly, Watanabe and Fukao [22] reported that an extract of unripe Japanese plum yew fruit (C. harringtonia) possessed, among 101 edible plants, the highest inhibitory effect against Bacillus cereus and Leuconostoc mesenteroides. Our results on the antimicrobial effect of SBCG and those of Korean and Japanese plum yew confirm the antibacterial potential of plants in the Cephalotaxus genus.

Another important aspect of this study is the observed cytotoxicity of three solvent SBCG extracts on HeLa cells and the apoptotic activity of the extracts. Results of 


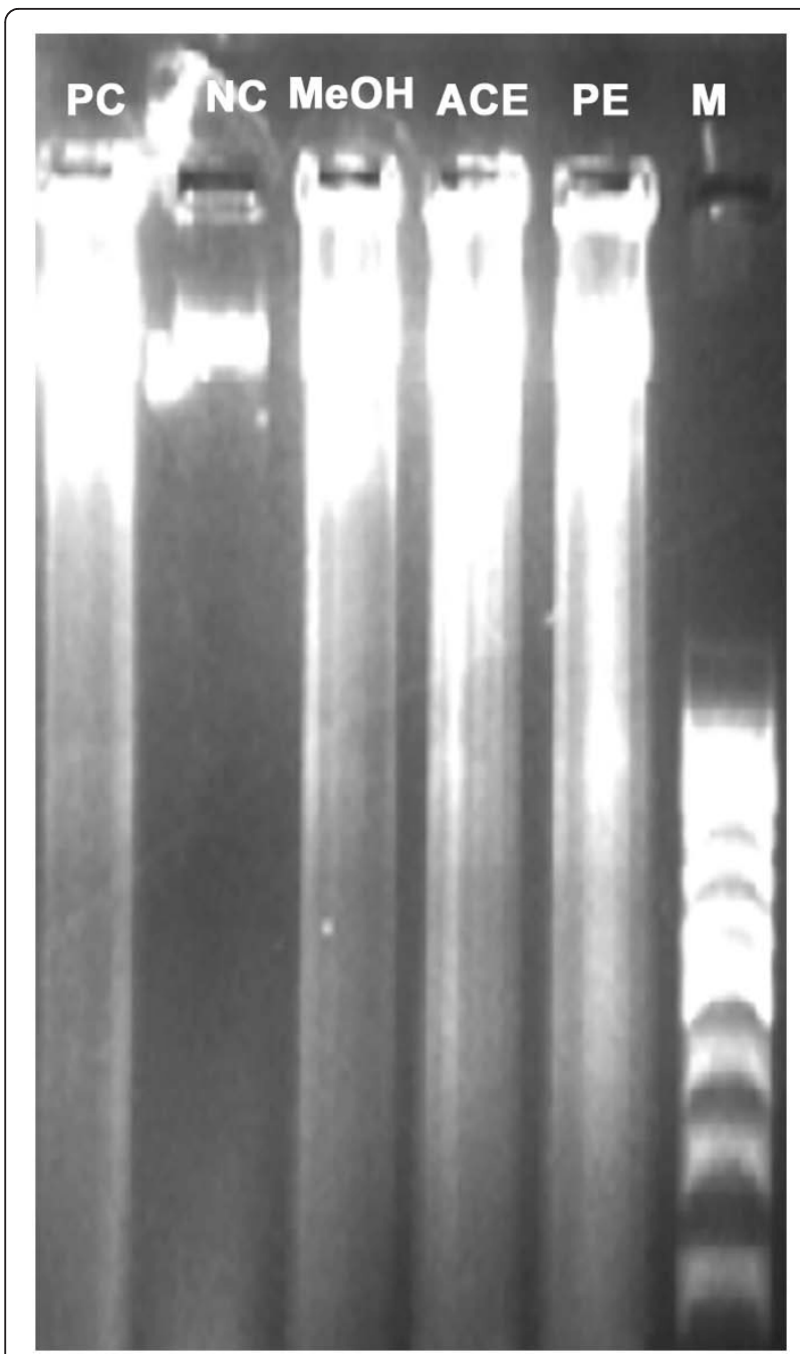

Figure $7 \mathrm{Gel}$ electrophoresis image obtained after DNA fragmentation assay for apoptosis detection. The lanes $P C, N C$, $\mathrm{PE}, \mathrm{ACE}, \mathrm{MeOH}$, and $\mathrm{M}$ represent treatment with the positive control (curcumin), negative control (no treatment), petroleum ether extract, acetone extract, methanol extract $\left(\mathrm{IC}_{50}\right)$, and marker (100 bp DNA ladder), respectively.

an MTT assay with SBCG indicated that the ACE extract was most effective in inducing cytotoxicity of HeLa cells. This was evident from the lowest $\mathrm{IC}_{50}$

Table 5 Effect of SBCG extracts $(80 \mu \mathrm{g} / \mathrm{ml})$ on sub-G0/G1 in HeLa cells

\begin{tabular}{ll}
\hline Treatment & Sub G0-G1 population (\%) \\
\hline Untreated & $2.9 \pm 0.6 \mathrm{a}$ \\
Petroleum ether & $9.1 \pm 0.8 \mathrm{a}$ \\
Acetone & $46.3 \pm 3.6 \mathrm{~b}$ \\
Methanol & $35.2 \pm 4.4 \mathrm{c}$ \\
\hline
\end{tabular}

Data expressed as mean \pm SD $(n=3)$

Means marked with different letters, within each column, are significantly different $(P<0.05)$
Table 6 Simple correlations ( $r$ value) between TPC and TFC in the SBCG extracts and their DPPH IC 50 and MTT $I_{50}$ values and sub-G0/G1 population

\begin{tabular}{ll}
\hline Correlations & $\boldsymbol{r}(\boldsymbol{P}<\mathbf{0 . 0 5})$ \\
\hline TPC and DPPH IC 50 & $0.936^{*}$ \\
TFC and DPPH IC 50 & $0.742^{*}$ \\
TPC and $M T T I C_{50}$ & $0.995^{*}$ \\
TFC and MTT IC 50 & $0.915^{*}$ \\
TPC and sub-G0/G1 population & $0.982^{*}$ \\
TFC and sub-G0/G1 population & $0.894^{*}$ \\
\hline
\end{tabular}

*Statistically significant at $P<0.05$

$(35.5 \pm 0.6 \mu \mathrm{g} / \mathrm{ml})$ of the ACE extract among the three extracts. In a previous study, a methylated biflavone, taiwanhomoflavone-A, isolated from $C$. wilsoniana, was found to possess high antiproliferative activity on $\mathrm{KB}$ epidermoid carcinoma of the nasopharynx, COLO-205 colon carcinoma, Hepa-3B hepatoma, and HeLa cervix tumor cells [2], with $\mathrm{ED}_{50}$ values of 3.4, 1.0, 2.0, and $2.5 \mu \mathrm{g} / \mathrm{ml}$, respectively. Similarly, two biflavonoids, namely ginkgetin and 4', 7"-Di-O-methyl-amentoflavone, from $C$. koreana were reported to show cytotoxicity against mouse osteoblasts [3]. There are 1100 publications reporting anticancer activities of polyphenols in the peer-reviewed journals [23] indicating that polyphenols are the main phytochemicals of higher plants possessing antiproliferative properties. We observed a statistically significant correlation between TPC ( $\mathrm{r}=$ 0.995, $\mathrm{P}<0.05) / \mathrm{TFC}(\mathrm{r}=0.915, \mathrm{P}<0.05)$ and MTT $\mathrm{IC}_{50}$, which explains the association of the high cytotoxic activity with polyphenol/flavonoid content in the SBCG. It is of interest to design future experiments to identify pure polyphenol/flavonoid molecules in SBCG with anticancer activities. To ascertain whether the cytotoxicity against HeLa cells was mediated through apoptosis, morphological, biochemical, and sub-G0/G1 population studies were carried out on treated HeLa cells. In the morphological study, most of the dead cells showed characteristic features of apoptosis such as cytoplasmic membrane blebbing, nuclear contraction, nuclear fragmentation, and contact inhibition (Figure 6) due to treatment with the extracts. These features were very prominent in the $\mathrm{ACE}$ and $\mathrm{MeOH}$ extracts. Biochemically, apoptosis is characterized by activation of endogenous nucleases and DNA degradation into fragment multiples of $185 \mathrm{bp}$ [24] which we observed in the DNA fragmentation assay (Figure 7). Furthermore, flow cytometry analysis of treated HeLa cells also showed that the sub-G0/G1 population, a biochemical marker of apoptosis [25] with hypo-diploid DNA, was significantly higher due to treatment with the ACE extract (46.3 \pm $3.6 \%)$ than with the $\mathrm{MeOH}$ extract $(35.2 \pm 4.4 \%)$ compared with control $(\mathrm{P}<0.05)$. This accumulation 
directly relates to decreases of the cell populations in other phases of the cell cycle, indicating cell death through interference of the cell program. Previous studies showed that polyphenolic compounds induce apoptosis [26,27]. Our study also showed that an increase in the total phenol/flavonoid content of the SBCG extracts significantly increased the rate of apoptosis as evident from the highly significant correlation of TPC/TFC with the sub-G0/G1 population (Table 6). Polyphenolic compounds induce apoptosis in cancer cells by increasing caspase activity [26,28]; upregulating the expression of p53, Bax, Bak, and Bim; and downregulating the expression of Bcl-2 and Bcl-XL [28].

\section{Conclusions}

Based on our results, we conclude that SBCG extracts contain bioactive components responsible for antioxidant, antibacterial, cytotoxic, and apoptotic activities. The polyphenol and flavonoid content of SBCG appears to be responsible for these biological activities. Among the extracts, the ACE extract was found to contain the highest amount of polyphenols and flavonoids and consequently exhibited the highest level of biological activity. We are currently separating and characterizing the bioactive components of the ACE extract of SBCG to test for potential applications in the human health sector.

\section{Methods}

\section{Chemicals}

Folin-Ciocalteu (FC) reagent; gallic acid; 2, 2-diphenyl-1picryl hydrazyl (DPPH); nitroblue tetrazolium (NBT); 3(4, 5-dimethyl-2-thiazolyl)-2, 5-diphenyl-tetrazolium bromide (MTT); acridine orange (AO); propidium iodide (PI); and cell culture chemicals were purchased from Sigma-Aldrich Chemicals Pvt. Ltd. (Mumbai, India). Ascorbic acid, curcumin, neomycin sulphate, penicillin, and riboflavin were purchased from HiMedia Laboratories Pvt. Ltd. (Mumbai, India). Proteinase-K, RNase, and ethidium bromide (EB) were purchased from Bangalore Genei (Bangalore, India). Quercetin was purchased from Ozone International, and the rest of the chemicals and solvents used were of analytical grade.

\section{Plant material}

The SBCG was collected from Kangchup Hills, Manipur, India (N24'52'10" E093 $46^{\prime} 12^{\prime \prime}$ ) at an elevation of $1534.668 \mathrm{~m}$ above sea level. The specimen was identified by Dr Biseshori Thongam, Plant Bioresources Division, Institute of Bioresources and Sustainable Development (IBSD), Manipur, India and by Dr S.K. Verma, National Bureau of Plant Genetics Resources, Meghalaya, India. A voucher specimen (IBSD/C/102) has been deposited to the IBSD herbarium.

\section{Preparation of SBCG extract}

The SBCG was air dried at room temperature and powdered. The powdered bark (100 g) was then exhaustively extracted serially by soaking (which prevents the loss of biological activity of some heat-sensitive ingredients) in $\mathrm{PE}, \mathrm{ACE}$, and $\mathrm{MeOH}$ in order to fractionate the phytochemical constituents into fractions or extracts. Filtration was performed and the filtrates were concentrated in vacuo using a vacuum rotary evaporator (EYELA, Japan) and finally freeze dried (Thermo, Modulyod). The dried extracts were kept at $4^{\circ} \mathrm{C}$ until further analysis.

\section{Test sample preparation}

Solutions of the test samples for the entire study of the $\mathrm{PE}$ extract were prepared in 1, 4-dioxan, except for the antibacterial study in which the sample was prepared in petroleum ether. The $\mathrm{ACE}$ and $\mathrm{MeOH}$ extracts test sample solutions used in the different experiments were prepared in DMSO. Reagent solutions were made in distilled water, unless otherwise specified.

\section{Determination of total phenolic content}

The TPC was determined using the FC reagent, following the procedure devised by Singleton and Rossi [29], with some modification. Briefly, $20 \mu \mathrm{l}$ extract $(500 \mu \mathrm{g} / \mathrm{ml})$ was mixed with $1.58 \mathrm{ml}$ distilled water. To this mixture, $100 \mu \mathrm{l}$ of FC reagent (1:2 dilutions) was added, followed by further addition of $300 \mu \mathrm{l}$ sodium carbonate $(1.8 \mathrm{M})$. This was incubated for $2 \mathrm{~h}$ at room temperature in the dark. The absorbance was then read at $765 \mathrm{~nm}$ using a UV-visible spectrophotometer (UV-1700 Pharmaspec, Shimadzu). The TPC was expressed as GAE in milligrams per gram extract after making a standard graph with five different concentrations of gallic acid (50-500 mg/l).

\section{Determination of total flavonoid content}

The TFC of SBCG extracts was determined by the method described by Woisky and Salatino [30]. To $0.5 \mathrm{ml}$ of each extract $(1 \mathrm{mg} / \mathrm{ml}), 0.5 \mathrm{ml}$ of $0.14 \mathrm{M}$ aluminum chloride ethanol solution was added. After $1 \mathrm{~h}$ at room temperature, the absorbance was measured at $420 \mathrm{~nm}$. The TFC was expressed as QE in milligrams per gram extract after making a standard graph with five different concentrations of quercetin $(12.5-200 \mu \mathrm{g} / \mathrm{ml})$.

\section{Scavenging activity of DPPH radical}

The free radical scavenging activity of the crude extracts was evaluated as described by Mensor et al. [31]. A solution of DPPH $(0.3 \mathrm{mM})$ in ethanol was prepared and $1 \mathrm{ml}$ added to different concentrations $(5-100 \mu \mathrm{g} / \mathrm{ml})$ of extract samples. After $30 \mathrm{~min}$ incubation at room temperature in the dark, absorbance values were measured at $517 \mathrm{~nm}$ in a UV-visible spectrophotometer. Ascorbic acid 
at different concentrations $(2-20 \mu \mathrm{g} / \mathrm{ml})$ was used as positive controls. The inhibition ratio (\%) was calculated as follows:

$\%$ inhibition $=[($ Absorbance of control - Absorbance of test sample $)]$ Absorbance of control] $\times 100$.

\section{Superoxide radical scavenging activity}

Measurement of SORS activity was carried out as described by Duan et al. [32], with a slight modification. Various concentrations $(5-100 \mu \mathrm{g} / \mathrm{ml})$ of test samples were mixed with $200 \mu \mathrm{l}$ EDTA $(0.1 \mathrm{M}), 100 \mu \mathrm{l}$ riboflavin (0.5 mM), $200 \mu \mathrm{l}$ ethanol, and $100 \mu \mathrm{l} \mathrm{NBT}(1.2 \mathrm{mM})$ and the mixture was diluted to $3 \mathrm{ml}$ with phosphate buffer ( $\mathrm{pH} 7.6$ ). The absorbance was then read at 560 $\mathrm{nm}$ after illumination for 15 minutes. Ascorbic acid was used as a positive control. The inhibition ratio (\%) was calculated as follows:

$\%$ inhibition $=[($ Absorbance of control - Absorbance of test sample $) /$ Absorbance of control] $\times 100$.

\section{Reducing power}

The reducing power was carried out as described by Oyaizu [33]. Various concentrations $(5-100 \mu \mathrm{g} / \mathrm{ml})$ of test samples were mixed with $2.5 \mathrm{ml}$ phosphate buffer $(0.2 \mathrm{M} ; \mathrm{pH}=6.6)$ and $2.5 \mathrm{ml}$ potassium ferricyanide $(0.03 \mathrm{M})$. After the mixture was incubated at $50^{\circ} \mathrm{C}$ for $20 \mathrm{~min}, 2.5 \mathrm{ml}$ of trichloroacetic acid $(0.6 \mathrm{M})$ was added, and the mixture was centrifuged at $1811 \mathrm{~g}$ for 10 min. Supernatant $(2.5 \mathrm{ml})$ was mixed with distilled water $(2.5 \mathrm{ml})$ and $0.5 \mathrm{ml}$ of ferric chloride $(6.1 \mathrm{mM})$. The absorbance was then read at $700 \mathrm{~nm}$. Ascorbic acid was used as a positive control.

\section{Bacterial strains}

The following bacterial strains, procured from Microbial Type Culture Collection (MTCC), Institute of Microbial Technology, Chandigarh, India, were used in the screening: Bacillus subtilis (MTCC2451), Bacillus cereus (MTCC430), and Pseudomonas aeruginosa (MTCC2581). Escherichia coli, Klebsiella pneumoniae, and Staphylococcus aureus were obtained from Dehradun Medical College, Dehradun, India.

\section{Preparation of discs}

Whatman filter paper (no.1) discs (5 mm diameter) were impregnated with $20 \mu \mathrm{l}$ of crude extracts to get a concentration of $1000 \mu \mathrm{g} / \mathrm{disc}$ and were kept at $37^{\circ} \mathrm{C}$ for $24 \mathrm{~h}$. The reference antibiotics (neomycin and penicillin) were prepared at appropriate concentrations ( $4 \mu \mathrm{g} / \mathrm{disc})$ to serve as the positive controls and solvents $\mathrm{PE}, \mathrm{ACE}$, and $\mathrm{MeOH}$ as the negative controls.

\section{Agar disc diffusion method}

A modified agar diffusion method was used to determine antibacterial activity [34]. The bacterial cells suspension, $1 \times 10^{6} \mathrm{cfu} / \mathrm{ml}$, was mixed with sterile nutrient agar and poured into petri dishes to give a solid plate.

The discs were deposited on the surface of inoculated agar plates. The bacterial plates were then incubated for $24 \mathrm{~h}$ at $37^{\circ} \mathrm{C}$. Inhibition zone diameters around each of the discs (diameter of inhibition zone plus diameter of the disc) were measured and recorded at the end of the incubation time. An average zone of inhibition was calculated for three replicates.

\section{Minimum inhibitory doses}

MID was determined by the disc diffusion method. Discs with graded doses (7.8-500 $\mu \mathrm{g} /$ disc) of extracts were prepared, with each consecutive disc containing double the amount of extract prior to when the agar disc diffusion test was performed. MIDs were also determined for positive control. The MID is the lowest quantity of the sample required to inhibit any visible growth.

\section{Cell culture}

The human cervical adenocarcinoma cell line (HeLa) was obtained from the National Centre for Cell Science (Pune, India). These were grown as monolayer cultures in DMEM (Dulbecco's modified Eagle's medium) supplemented with $10 \%(\mathrm{v} / \mathrm{v})$ heat-inactivated fetal bovine serum (FBS) and 1\% antibiotic antimycotic solution (1000 U/ml penicillin, $10 \mathrm{mg} / \mathrm{ml}$ streptomycin sulfate, 5 $\mathrm{mg} / \mathrm{ml}$ gentamycin, and $25 \mu \mathrm{g} / \mathrm{ml}$ amphotericin-B), and maintained at $37^{\circ} \mathrm{C}$ in $5 \% \mathrm{CO}_{2} / 95 \%$ air with $90 \%$ relative humidity.

\section{MTT reduction assay on HeLa cells}

Cytotoxicity analysis was determined using the MTT assay as reported by Mosmann [35]. HeLa cells grown in T-25 culture flasks were harvested by trypsinization, plated at an approximate density of $1 \times 10^{5}$ cells/well in 96-well culture plates (Corning, Sigma), and incubated for $24 \mathrm{~h}$ to achieve confluency. Next the medium from each well was removed and the cells washed twice with Dulbecco's phosphate buffered saline (PBS). The cells were then exposed to increasing concentrations of extract $(5-80 \mu \mathrm{g} / \mathrm{ml})$. Each well contained $100 \mu \mathrm{l}$ of serum-free DMEM containing different concentrations of extracts. The cells were then incubated at $37^{\circ} \mathrm{C}$ in $5 \%$ $\mathrm{CO}_{2} / 95 \%$ air with $90 \%$ relative humidity for $24 \mathrm{~h}$. After incubation, the contents were replaced with equal amounts of MTT dissolved in serum-free DMEM (1.2 $\mathrm{mM}$ ) after which the plates were further incubated for 3 h. The contents were then replaced with equal amounts of DMSO to solubilize the formazan grains formed by viable cells. Finally, the absorbance was read at $570 \mathrm{~nm}$ 
using a multi-well plate reader (Tecan, Infinite M200). The viability percentage was calculated by using the formula below:

Viability $\%=$ Absorbance of test sample $\times 100 /$ Absorbance of solvent control

\section{Fluorescence microscopy}

Differential staining of extract-treated $(80 \mu \mathrm{g} / \mathrm{ml} ; 24 \mathrm{~h})$ and untreated HeLa cells was done using DNA-intercalate fluorescent dyes $\mathrm{EB}$ and $\mathrm{AO}$ [36], and analyzed under a fluorescence microscope (Nikon, TS 100-F; Tokyo, Japan).

\section{DNA fragmentation assay}

For laddering experiments, HeLa cells $\left(2 \times 10^{6}\right.$ cells/ well) were cultured in 6-well culture plates (Corning, Sigma), treated with extracts (MTT test $\mathrm{IC}_{50}$ value) and incubated for $48 \mathrm{~h}$ in a $\mathrm{CO}_{2}$ incubator. Treated cells were then harvested, washed with ice-cold PBS ( $\mathrm{pH} 7.2)$, and centrifuged at $0.8 \mathrm{~g}$ for $6 \mathrm{~min}$ at $4^{\circ} \mathrm{C}$. The resulting cell pellet was dispersed in $30 \mu \mathrm{l}$ of lysis buffer $(10 \mathrm{mM}$ EDTA; $50 \mathrm{mM}$ Tris $\mathrm{HCl}, \mathrm{pH}-7.8 ; 1 \%$ SDS) by gentle vortexing. About $4 \mu \mathrm{l}$ of proteinase-K $(10 \mu \mathrm{g} / \mu \mathrm{l})$ was then added to the above mixture, followed by incubation at $45^{\circ} \mathrm{C}$ for $1-2 \mathrm{~h}$. Then, $2 \mu \mathrm{l}$ of RNase $(10 \mu \mathrm{g} / \mu \mathrm{l})$ was added to the cell lysates, which were further incubated for $1 \mathrm{~h}$ at room temperature. After incubation cell lysates were mixed with $4 \mu \mathrm{l}$ of $6 \mathrm{X}$ DNA sample dye and subjected to run at $2 \%$ agarose gel electrophoresis. The gel was then stained with ethidium bromide $(0.5$ $\mu \mathrm{g} / \mathrm{ml}$ ) and visualized under a gel documentation system (Bio-Rad, USA).

\section{Flow cytometry}

Apoptotic cells were detected using PI staining [37] of HeLa cells followed by flow cytometry to detect the sub-G0/G1 cell population [38]. Briefly, HeLa cells were treated with or without SBCG extract $(80 \mu \mathrm{g} / \mathrm{ml})$ for 24 h. After treatment, floating and adherent cells were harvested and fixed in ice-cold $70 \%$ ethanol overnight at $-20^{\circ} \mathrm{C}$. Fixed cells were then treated with $0.5 \mathrm{ml}$ of DNA extraction buffer $\left(192 \mathrm{ml}\right.$ of $0.2 \mathrm{M} \mathrm{Na}_{2} \mathrm{HPO}_{4}$ with $8 \mathrm{ml}$ of $0.1 \%$ Triton $\mathrm{X}-100(\mathrm{v} / \mathrm{v}))$ for $5 \mathrm{~min}$ at room temperature. DNA was stained with PI $(0.02 \mathrm{mM})$ and incubated for $1 \mathrm{~h}$ in the dark. Flow cytometric analysis was then performed using a flow cytometer (BD FACSCaliber). At least 10,000 cells were analyzed for each sample and data were analyzed and plotted by CellQuest software.

\section{Statistical analysis}

The values are presented as mean \pm SD (standard deviation) of triplicate measurements. Multiple comparisons between more than two groups were performed by oneway ANOVA supplemented with Tukey's HSD post hoc test. Values at $\mathrm{P}<0.05$ were considered to indicate statistical significance. Simple correlation analysis was carried out and significance tested by following standard methods [39].

\section{Acknowledgements and funding}

The senior author thanks the Institute of Bioresources and Sustainable Development (IBSD), Imphal and Department of Biotechnology, Government of India for the PhD-JRF fellowship. The technical help of Mr Lokesh Deb, Dr Reena Langoljam, and Miss Surbala Laishram of IBSD and Mr Arghya Sett of IIT, Guwahati is duly acknowledged.

\section{Author details}

${ }^{1}$ Institute of Bioresources and Sustainable Development, Department of Biotechnology, Government of India, Takyelpat Institutional Area, Imphal 795001, Manipur, India. ${ }^{2}$ Indian Institute of Technology Guwahati, Department of Biotechnology, Guwahati 781039, Assam, India.

\section{Authors' contributions}

DSM: performed the entire experiment and prepared the manuscript. NCT: designed the research plan; supervised and coordinated the study; and corrected the manuscript. NK and UB: assisted, along with DSM, in conducting the cell culture-based experiment. All authors have duly checked and approved the manuscript before submission.

\section{Competing interests}

The authors declare that they have no competing interests.

Received: 2 December 2011 Accepted: 3 April 2012

Published: 3 April 2012

\section{References}

1. Uma S: Blooming potential of the detached shoots of Cephalotaxus griffithii Hook. f. Curr Sci 2008, 95:320-321.

2. Kuo Y-H, Lin C-H, Hwang S-Y, Shen Y-C, Lee Y-C, Li S-Y: Novel cytotoxic Cmethylated biflavone from the stem of Cephalotaxus wilsoniana. Chem Pharm Bull 2000, 48:440-441.

3. Lee MK, Lin SW, Yang H, Sung HS, Lee H-S, Park MJ, Kim YC: Osteoblast differentiation stimulating activity of biflavonoids from Cephalotaxus koreana. Bioorg Medicinal Chem Lett 2006, 16:2850-2854.

4. Bae K, Jin W, Thoung PT, Min BS, Na M, Lee YM, Kang SS: A new flavonoid glycoside from the leaf of Cephalotaxus koreana. Fitoterapia 2007, 78:409-413.

5. Kamil M, Khan NA, Ahmad I, liyas M, Rahman W: Chemical constituents of Cephalotaxus griffithii. J Indian Chem Soc 1982, 59:1199.

6. Phutdhawong W, Korth J, Budhasukh D, Pyne SG: Volatile components from Cephalotaxus griffithii growing in northern Thailand. Flavour Fragr J 2002, 17:153-155.

7. Plouvier $\mathrm{V}$ : Cephalotaxoside, a new apigenin heteroside isolated from Cephalotaxus. Presence of rhoifolin in Exochorda and Lupinus. C.r.Acad. sci, Ser.D: Sciences Naturelles 1966, 263:1529-1532

8. Wang L-W, Su H-J, Yang S-Z, Won S-J, Lin C-N: New alkaloids and a tetraflavonoid from Cephalotaxus wilsoniana. J Nat Prod 2004, 67:1182-1185.

9. Gamet-Payrastre L, Manenti S, Gratacap MP, Tulliez J, Chap H, Payrastre B: Flavonoids and the inhibition of PKC and PI 3-kinase. Gen Pharmacol 1999, 32:279-286.

10. Middleton E Jr, Kandaswami C, Theoharides TC: The effects of plant flavonoids on mammalian cells: implications for inflammation, heart disease and cancer. Pharmacol Rev 2000, 52:673-751.

11. Nichols JA, Katiyar SK: Skin photoprotection by natural polyphenols: antiinflammatory, antioxidant and DNA repair mechanisms. Arch Dermatol Res 2010, 302:71-83.

12. Yuan $\mathrm{YV}$, Walsh NA: Antioxidant and antiproliferative activities of extracts from a variety of edible seaweeds. Food Chem Toxicol 2006, 44:1144-1150. 
13. Rao ASVC, Reddy SG, Babu PP, Reddy AR: The antioxidant and antiproliferative activities of methanolic extracts from Njavara rice bran. BMC Complem Altern Med 2010, 10:4.

14. Carvalho M, Ferreira PJ, Mendes VS, Silva R, Pereira JA, Jerónimo C, Silva BM: Human cancer cell antiproliferative and antioxidant activities of Juglans regia L. Food Chem Toxicol 2010, 48:441-447.

15. Kook D, Wolf AH, Yu AL, Neubauer AS, Priglinger SG, Kampik A, WelgeLüssen UC: The protective effect of quercetin against oxidative stress in the human RPE in vitro. Invest Ophthalmol Vis Sci 2008, 49:1712-1720.

16. Nabavi SF, Eslami S, Moghaddam AH, Nabavi SM: Protective effects of curcumin against fluoride-induced oxidative stress in the rat brain. Neurophysiology 2011, 43:287-291

17. Nabavi SF, Moghaddam AH, Eslami S, Nabavi SM: Protective effects of curcumin against sodium fluoride-induced toxicity in rat kidneys. Biol Trace Elem Res 2012, 145:369-374

18. Shon M-Y, Kim T-H, Sung N-J: Antioxidants and free radical scavenging activity of Phellinus baumii (Phellinus of Hymenochaetoceae) extracts. Food Chem 2003, 82:593-597.

19. Scalbert A: Antimicrobial properties of tannins. Phytochemistry 1991, 30:3875-3883.

20. Cowan MM: Plants products as antimicrobial agents. Clin Microbiol Rev 1999, 12:564-582.

21. Cho CH, Yoo G, Kim S, Lee G-S, Kim J-H, Hyun J-O, Chae HJ: Antimicrobial activity and cell cytotoxicity of Korean Plum-yem extract. J App/ Biol Chem 2009, 52:45-50.

22. Watanabe K, Fukao T: Antibacterial effects of unripe Cephalotaxus harringtonia fruit extract on gram-positive bacteria. J Jpn Soc Food Sci Technol 2009, 56:533-540

23. Lamoral-Theys D, Pottier L, Dufrasne F, Nève J, Dubois J, Kornienko A, Kiss R, Ingrassia L: Natural polyphenols that display anticancer properties through inhibition of kinase activity. Curr Med Chem 2010, 17:812-825.

24. Bortner CD, Oldenburg NBE, Cidlowski JA: The role of DNA fragmentation in apoptosis. Trends Cell Biol 1995, 5:21-26.

25. Yu J, Liu H, Lei J, Tan W, Hu X, Zou G: Antitumor activity of chloroform fraction of Scutellaria barbata and its active constituents. Phytother Res 2007, 21:817-822.

26. Wolter F, Akoglu B, Clausnitzer A, Stein J: Downregulation of the cyclin D1/Cdk4 complex occurs during resveratrol-induced cell cycle arrest in colon cancer cell lines. J Nutr 2001, 131:2197-2203.

27. Shankar S, Srivastava RK: Involvement of Bcl-2 family members, phosphatidylinositol 3'- kinase/AKT and mitochondrial p53 in curcumin (diferulolylmethane)-induced apoptosis in prostate cancer. Int J Oncol 2007, 30:905-918.

28. Kim YA, Lee $W H$, Choi TH, Rhee SH, Park KY, Choi YH: Involvement of p21WAF1/CIP1, pRB, Bax and NF-kappaB in induction of growth arrest and apoptosis by resveratrol in human lung carcinoma A549 cells. Int J Oncol 2003, 23:1143-1149.

29. Singleton VL, Rossi JA: Colorometry of total phenolics with phosphomolybdic-phosphotungstic acid reagents. Amer J Enol Viticult 1965, 16:144-158.

30. Woisky RG, Salatino A: Analysis of propolis: Some parameters and procedures for chemical quality control. J Apicult Res 1998, 37:99-105.

31. Mensor LL, Menezes FS, Leitao GG, Reis AS, Santos TC, Coube CS, Leitao SG: Screening of Brazilian plant extracts for antioxidant activity by the use of DPPH free radical method. Phytother Res 2001, 15:127-130.

32. Duan $X, W u G$, Jiang $Y$ : Evaluation of anti oxidant properties of phenolics from lichi fruit in relation to pericarp browning prevention. Molecules 2007, 12:759-771.

33. Oyaizu M: Studies on products of the browning reaction. Antioxidative activities of browning reaction products prepared from glucosamine. Jpn J Nutr 1986, 44:307-314.

34. Bauer AW, Kirby WMM, Sherris JC, Turck M: Antibiotic susceptibility testing by a standardized single disk method. Am J Clin Pathol 1966, 45:493-496.

35. Mosmann T: Rapid colorimetric assay for cellular growth and survival: application to proliferation and cytotoxicity assays. J Immunol Methods 1983, 65:55-63.

36. Patel S, Kasoju N, Bora U, Goyal A: Structural analysis and biomedical applications of dextran produced by a new isolate Pediococcus pentosaceus screened from biodiversity hot spot Assam. Bioresource Technol 2010, 101:6852-6855.
37. Riccardi C, Nicoletti I: Analysis of apoptosis by propidium iodide staining and flow cytometry. Nat Protoc 2006, 1:1458-1461.

38. Fuke H, Shiraki K, Sugimoto K, Tanaka J, Beppu T, Yoneda K, Yamamoto N, Ito K, Masuya M, Takei Y: Jak inhibitor induces S phase cell-cycle arrest and augments TRAIL-induced apoptosis in human hepatocellular carcinoma cells. Biochem Biophys Res Commun 2007, 363:738-744.

39. Kwanchai AG, Arturo AG: Statistical procedures for agricultural research Singapore: John Wiley and Sons, Inc; 1984.

Pre-publication history

The pre-publication history for this paper can be accessed here: http://www.biomedcentral.com/1472-6882/12/30/prepub

doi:10.1186/1472-6882-12-30

Cite this article as: Moirangthem et al:: Antioxidant, antibacterial, cytotoxic, and apoptotic activity of stem bark extracts of Cephalotaxus griffithii Hook. f. BMC Complementary and Alternative Medicine 2012 12:30.

\section{Submit your next manuscript to BioMed Central and take full advantage of:}

- Convenient online submission

- Thorough peer review

- No space constraints or color figure charges

- Immediate publication on acceptance

- Inclusion in PubMed, CAS, Scopus and Google Scholar

- Research which is freely available for redistribution

Submit your manuscript at www.biomedcentral.com/submit
C) Biomed Central 